\title{
ASSESSMENT OF SELECTED HEAVY METALS AND ESTIMATION OF HUMAN HEALTH RISK IN SOME COMMONLY CONSUMED FISH IN ABEOKUTA, OGUN - STATE, NIGERIA
}

\author{
T. F. Akinhanmi, F. ${ }^{*}{ }^{*}$ Akinwunmi, ${ }^{1}$ O. O. Ajala ${ }^{1}$ and E. E. Usanga ${ }^{1}$ \\ ${ }^{1}$ Department of Chemistry, College of Physical Sciences, Federal University of Agriculture, Abeokuta, \\ Ogun State, Nigeria \\ *Corresponding Author's e-mail:tfakins1@yahoo.com +2348037269670 \\ Received 10 March 2021; accepted 29 March 2021, published online 3 April 2021
}

\begin{abstract}
Fish is a major source of food in many parts of the world because they contribute to solving the global food problem and provide the well-known proteins, minerals, vitamin and trace elements content. Concentrations of iron $(\mathrm{Fe})$, zinc $(\mathrm{Zn})$, copper $(\mathrm{Cu})$, nickel $(\mathrm{Ni})$, lead $(\mathrm{Pb})$ and cadmium $(\mathrm{Cd})$ were determined in various parts of the fish (liver, gill, bone and muscle) of Mackerel (Scomber scombrus), Sardine (Sardinella longiceps), Hake (Merluccius merluccius) and Express (Platax scalaris) which were purchased from two major markets in Abeokuta, Ogun State, Nigeria. Heavy metal levels in the fish samples were analyzed by Atomic Absorption Spectrophotometer (AAS Buck 211). Health risks related to $\mathrm{Fe}, \mathrm{Zn}, \mathrm{Cu}, \mathrm{Ni}, \mathrm{Pb}$ and $\mathrm{Cd}$ were assessed based on target hazard quotient (THQ). Results obtained showed variations in the levels of heavy metals across the various tissues in the fish samples. The concentration of $\mathrm{Fe}$ was highest in all the tissues in the fish samples with the gill recording the highest level. There were higher concentrations of heavy metals in the gills than in other tissues of the fish samples. The trend of heavy metal levels in the tissues was found to be $\mathrm{Fe}>\mathrm{Zn}>\mathrm{Cu}>\mathrm{Ni}>\mathrm{Pb}>\mathrm{Cd}$. Highest levels of $\mathrm{Pb}$ and $\mathrm{Cd}$ in the muscle were $1.92 \pm 0.04$ and $0.64 \pm 0.04 \mathrm{mg} / \mathrm{kg}$ in Merlucciusmerloccius and Scomberscombrus respectively. The concentrations of $\mathrm{Pb}$ and $\mathrm{Cd}$ were higher in the muscles of all the samples than European Community and Food and Agriculture Organization maximum permissible levels. The health risks from $\mathrm{Ni}$ and $\mathrm{Pb}$ were found highest among all the heavy metals in the fish samples. THQ values of $\mathrm{Cu}$ and $\mathrm{Cd}$ in Sardinellalongiceps and $\mathrm{Cu}$ in Merlucciusmerloccius were higher than 1 . Health risk assessment of $\mathrm{Ni}$ and $\mathrm{Pb}$ in all the fish studied and $\mathrm{Cd}$ in Sardinellalongiceps indicates that their consumption may be unsafe.

Keywords: Heavy metals; Target Hazard Quotient; Maximum permissible level; Health risk assessment.
\end{abstract}

\section{Introduction}

Global food problem is potentially solved by the existence of fish and fish products which are important for human consumption in many parts of the world. Fish products provide proteins, minerals, vitamins and trace elements contents in human diet. Heavy metals from anthropogenic sources are continually released into the aquatic and terrestrial ecosystems. Contamination with heavy metals is a serious threat due to their toxicity, bioaccumulation and biomagnification in the food chain [1] and also its nonbiodegradable properties in food [2]. Industrial wastes and mining can create a potential source of heavy metal pollution in aquatic environment $[3,4]$. Heavy metal pollution in rivers is a threat to public water supplies and also to consumer of fishery sources [5]. Heavy metals enter into fish bodies by three possible ways: gills, digestive tract and body surface. The gills are considered as the significant site for direct uptake of metals from the water $[\mathbf{6}, 7]$, though the body surface is normally estimated to take minor part in uptake of heavy metals in fish [8]. Human health may be affected by organic and inorganic pollutants associated with aquatic systems by consumption of contaminated fish and other aquatic foods from the environment [9]. Heavy metals might accumulate up to toxic concentration under certain environmental conditions and cause ecological damage [10]. Metals such as iron, copper, zinc and manganese are essential metals since they play important role in biological systems, whereas mercury, lead and cadmium are toxic even in trace amounts. The essential metals can also produce toxic effects when present in high concentrations [11]. Fish, among other animals are used to determine the health condition of aquatic ecosystem $[\mathbf{1 2}, \mathbf{1 3}]$. Heavy metals in fish come mainly from their diet, and 
levels of bioaccumulation of contaminants are higher in fish which are higher in the food chain [14]. The pattern of heavy metal uptake in fish varies in different species depending on factors such as lipid content in the tissue, mode of feeding and age of the fish [15]. Different factors such as physical and chemical properties of water as well as seasonal changes are the reasons for significant augmentation of metals in different fish tissues [16, 17]. Metal residual problems in the fish epithelium are stern, because of the presence of higher metal concentrations in water and sediments $[\mathbf{1 8}]$. The awareness of the Nigerian populace of the benefits of fish consumption appears to have increased in recent times. Therefore, it is pertinent to investigate the concentrations of heavy metals in some regularly consumed fish from the aquatic environment to establish the level of contamination and risks to human health.

\section{Experiment}

\section{Materials}

All the chemicals used were of analar grade. Concentrated Hydrochloric acid, Nitric acid and Sodium hydroxide were obtained commercially from BDH, Fish samples, Mackerel (Scomber scombrus), Sardine (Sardinella longiceps), Express (Platax scalaris) and Hake (Merluccius merluccius) were purchased from two major markets (Lafenwa and Obantoko) in Abeokuta, Ogun State, Nigeria.

\section{Sample treatment}

The gills, bones, scales, livers and muscles were removed with stainless steel knife, washed with distilled water, mopped dry and weighed. The different parts were dried to constant weights in the oven at temperature of $70-80^{\circ} \mathrm{C}$. The dried samples were crushed into a fine powdered form by using pestle and mortal and then sieved.

\section{Digestion of fish samples}

Each ground portion (gill, bone, scale, liver and muscle) from the various fish samples was treated by acid digestion. Into $100 \mathrm{~mL}$ conical flask was weighed $0.5 \mathrm{~g}$ of each sample and then digested with $10 \mathrm{~mL}$ concentrated $\mathrm{HNO}_{3}$ on a hotplate at a temperature range between $60-80$ ${ }^{\circ} \mathrm{C}$ for a period of 8 hours. Each digested sample was filtered and made up to $20 \mathrm{~mL}$ with $5 \%$ nitric acid solution. The solutions obtained were transferred into the pre-labelled sample bottles for metal analysis using Atomic Absorption Spectrophotometer BUCK 211.

\section{Blank Digestion}

The blank digestion was carried out with $10 \mathrm{~mL}$ of concentrated nitric acid on a hotplate at a temperature of $60-80{ }^{\circ} \mathrm{C}$ for a period of 8 hours. The digested blank was made up $20 \mathrm{~mL}$ with 5\% nitric acid solution and transferred into sample bottles.

\section{Human health risk assessment}

Health risk assessment is a very important tool to evaluate the consequences of human action and measures the adverse effect to public health. Results acquired from the muscle of fish samples were used in the determination of the health risk from consumption of the fish samples.

\section{Target Hazard Quotient}

Concentrations of heavy metals in the muscle of the various fish samples was employed to estimate the daily intake of heavy metals using Equation 1:

$$
T H Q=\frac{(E F r \times E D \times F i R \times C) 10^{-3}}{R f D \times W a B \times T A}
$$

where, THQ is the Target Hazard Quotient; EFr is the Exposure Frequency (350 days/year); ED is Exposure Duration (54.4 years), equivalent to the average lifetime (life expectancy for Nigerian adult); FiR is the Fish ingestion Rate (20 g/day/Nigerian person); $\mathrm{C}$ is the concentration of metal in the muscle of fish $(\mu \mathrm{g} / \mathrm{g})$; RfDs is the oral Reference Doses: $\mathrm{Fe}=$ $0.7, \mathrm{Zn}=0.3, \mathrm{Cu}=0.04, \mathrm{Ni}=0.02, \mathrm{~Pb}=0.0005$ and $\mathrm{Cd}=0.001 \mathrm{mg} / \mathrm{kg}$ respectively [19]; $\mathrm{WaB}$ is the average body weight $(60.7 \mathrm{~kg})$ and $\mathrm{TA}$ is the average exposure time for non-carcinogens (365 days/year) [19].

\section{Estimation of the allowable daily consumption rates $\left(\mathbf{C R}_{\text {lim }}\right)$}

In order to determine the allowable daily consumption rate of the fish samples, equation 2 was applied. Unit was expressed in $\mathrm{kg} /$ day.

$$
C R_{\lim }=\frac{R f D \times B w}{C m}
$$

Where, $\mathrm{CR}_{\lim }$ is the maximum safe daily consumption rate of fish $(\mathrm{kg} / \mathrm{d})$; RfD is the reference doses of metal $(\mathrm{mg} / \mathrm{kg} / \mathrm{d}) ; \mathrm{Bw}$ is the average consumer body weight $(60.7 \mathrm{~kg}) ; \mathrm{C}_{\mathrm{m}}$ is the measured concentration of chemical in the 
fish (mg/g). RfD values were found on the basis of daily consumption of metals over a life span that would not be supposed to cause any adverse effects on health of human [19].

Estimation of allowable weekly and monthly consumption rates $\left(\mathbf{C R}_{\mathrm{wm}}\right.$ and $\left.\mathbf{C} \mathbf{R}_{\mathrm{mm}}\right)$

The allowable weekly $\left(\mathrm{CR}_{\mathrm{wm}}\right)$ and monthly consumption rates $\left(\mathrm{CR}_{\mathrm{mm}}\right)$ were estimated using Equations 3 and 4 respectively:

$C R_{\text {wm }}=C R_{\text {lim }} \times 7$

Where, $\mathrm{CR}_{\mathrm{wm}}$ is the maximum weekly consumption rate of fish ( $\mathrm{kg} / \mathrm{week}), \mathrm{CR}_{\mathrm{lim}}$ is the maximum safe daily consumption rate of fish $(\mathrm{kg} / \mathrm{d})$ over 7 days per week.

$C R_{m m}=\left(C R_{w m} \times T a p\right) M S^{-1}$
Where, $\mathrm{CR}_{\mathrm{mm}}$ is the maximum allowable fish consumption rate (meals month ${ }^{-1}$ ), $\mathrm{CR}_{\mathrm{wm}}$ is the maximum weekly consumption rate of fish (kg/week), Tap is the average weeks in a month (taken as 4.3 week/month ${ }^{-1}$ ), and MS is the meal

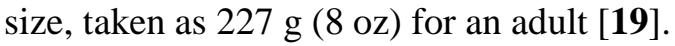

\section{Hazard Index (HI)}

For the risk assessment of multiple heavy metals (3oontained in fish, a total hazard index (HI) was estimated using Equation 5:

$\mathrm{HI}=\mathrm{THQ}(\mathrm{Fe})+\mathrm{THQ}(\mathrm{Zn})+\mathrm{THQ}(\mathrm{Cu})+\mathrm{THQ}(\mathrm{Ni})$ where, THQ is the target hazard quotient of an individual element of heavy metals and $\mathrm{HI}$ is the ... total hazar(d4i)dex [19].

\section{Results and Discussion}

Table 1: Mean concentrations ( $\mathrm{mg} / \mathrm{kg}$ ) of heavy metals in various fish samples studied

\begin{tabular}{|c|c|c|c|c|c|c|c|}
\hline Fish species & Tissues & $\mathbf{F e}$ & $\mathbf{Z n}$ & $\mathbf{C u}$ & $\mathbf{N i}$ & $\mathbf{P b}$ & Cd \\
\hline & Bone & $5.96 \pm 0.08^{\mathrm{d}}$ & $2.64 \pm 0.12^{d}$ & $1.44 \pm 0.80^{\mathrm{e}}$ & $1.04 \pm 0.04^{\mathrm{c}}$ & $0.72 \pm 0.08$ & ND \\
\hline & Gill & $6.04 \pm 0.04^{\mathrm{c}}$ & $3.00 \pm 2.80^{\mathrm{e}}$ & $2.24 \pm 0.80^{\mathrm{e}}$ & $1.80 \pm 0.12^{\mathrm{f}}$ & $1.24 \pm 0.04^{\mathrm{c}}$ & ND \\
\hline & Liver & $5.92 \pm 0.04^{\mathrm{d}}$ & $3.12 \pm 0.08^{\mathrm{e}}$ & $2.04 \pm 0.08^{\mathrm{e}}$ & $1.4 \pm 0.04^{\mathrm{g}}$ & $1.28 \pm 0.08^{\mathrm{f}}$ & $0.64 \pm 0.04^{\mathrm{d}}$ \\
\hline Scomber & Muscle & $5.48 \pm 0.24^{\mathrm{c}}$ & $2.76 \pm 0.20^{\mathrm{d}}$ & $1.72 \pm 4.00^{\mathrm{ef}}$ & $1.28 \pm 0.20^{\mathrm{c}}$ & $0.36 \pm 0.08^{\mathrm{f}}$ & ND \\
\hline & Bone & $6.12 \pm 0.08^{\mathrm{c}}$ & $3.36 \pm 0.00^{\mathrm{c}}$ & $2.52 \pm 0.00^{\mathrm{c}}$ & $1.92 \pm 0.00^{b}$ & $0.84 \pm 0.08^{\mathrm{c}}$ & ND \\
\hline & Gill & $6.28 \pm 0.08^{c}$ & $4.56 \pm 0.08^{c}$ & $3.44 \pm 0.12^{\mathrm{d}}$ & $2.96 \pm 0.04^{\mathrm{c}}$ & $1.68 \pm 0.04^{\mathrm{d}}$ & ND \\
\hline & Liver & $4.84 \pm 0.04^{\mathrm{f}}$ & $3.98 \pm 0.08^{\mathrm{c}}$ & $3.32 \pm 0.04^{\mathrm{d}}$ & $2.92 \pm 0.12^{\mathrm{a}}$ & $1.76 \pm 0.08^{\mathrm{d}}$ & $0.60 \pm 0.40^{\mathrm{b}}$ \\
\hline ps & Muscle & $5.88 \pm 6.00^{c}$ & $3.16 \pm 6.80^{c}$ & $2.64 \pm 0.48^{\mathrm{c}}$ & $2.56 \pm 0.04^{\mathrm{a}}$ & $1.28 \pm 0.04^{\mathrm{b}}$ & $0.60 \pm 4.00^{\mathrm{b}}$ \\
\hline & Bone & $4.00 \pm 4.00^{\mathrm{f}}$ & $2.84 \pm 0.08^{\mathrm{d}}$ & $2.28 \pm 0.00^{\mathrm{c}}$ & $1.52 \pm 0.00^{b}$ & $0.88 \pm 0.04^{\mathrm{c}}$ & ND \\
\hline & Gill & $4.92 \pm 4.40^{\mathrm{d}}$ & $3.28 \pm 0.04^{\mathrm{d}}$ & $2.44 \pm 0.08^{\mathrm{d}}$ & $2.28 \pm 0.00^{\mathrm{f}}$ & $1.76 \pm 0.04^{\mathrm{d}}$ & ND \\
\hline & Liver & $4.00 \pm 0.12^{\mathrm{g}}$ & $3.36 \pm 0.04^{\mathrm{d}}$ & $2.28 \pm 0.16^{\mathrm{d}}$ & $1.88 \pm 0.08^{\mathrm{d}}$ & $1.44 \pm 0.08^{\mathrm{d}}$ & ND \\
\hline Platax scalaris $(\mathrm{mg} / \mathrm{kg})$ & Muscle & $4.00 \pm 4.00^{\mathrm{ef}}$ & $2.84 \pm 0.80^{\mathrm{c}}$ & $2.24 \pm 0.16^{\mathrm{c}}$ & $1.88 \pm 0.08^{\mathrm{b}}$ & $1.36 \pm 0.04^{\mathrm{b}}$ & ND \\
\hline \multirow{4}{*}{$\begin{array}{l}\text { Merluccius merluccius } \\
(\mathrm{mg} / \mathrm{kg})\end{array}$} & Bone & $5.48 \pm 0.40^{\mathrm{d}}$ & $4.32 \pm 0.28^{b}$ & $3.68 \pm 0.00^{\mathrm{a}}$ & $1.92 \pm 0.32^{\mathrm{d}}$ & $1.24 \pm 0.04^{\mathrm{b}}$ & ND \\
\hline & Gill & $6.08 \pm 0.28^{\mathrm{c}}$ & $4.92 \pm 0.04^{\mathrm{b}}$ & $4.08 \pm 0.04^{\mathrm{a}}$ & $3.28 \pm 0.08^{\mathrm{b}}$ & $2.32 \pm 0.00^{\mathrm{b}}$ & ND \\
\hline & Liver & $5.96 \pm 0.04^{\mathrm{d}}$ & $4.72 \pm 0.08^{b}$ & $3.68 \pm 0.08^{\mathrm{a}}$ & $2.40 \pm 0.08^{\mathrm{c}}$ & $2.08 \pm 0.04^{\mathrm{a}}$ & ND \\
\hline & Muscle & $5.48 \pm 0.8^{\mathrm{cd}}$ & $4.32 \pm 0.28^{\mathrm{b}}$ & $3.68 \pm 0.04^{\mathrm{a}}$ & $2.32 \pm 0.08^{\mathrm{a}}$ & $1.92 \pm 0.04^{\mathrm{a}}$ & ND \\
\hline
\end{tabular}

Values expressed as Mean \pm Standard deviation with different superscripts in column are significantly different $(p<0.05)$

The mean concentrations $(\mathrm{mg} / \mathrm{kg})$ of heavy metals in various fish species studied are represented in Table 1. In Scomber scombrus, Fe concentration was the highest in bone, gill, liver and muscle with the values ranging from $5.48 \pm$ 0.24 to $6.04 \pm 0.04 \mathrm{mg} / \mathrm{kg}$. Cd $(0.64 \pm 0.04$ $\mathrm{mg} / \mathrm{kg}$ ) was only detected in the liver. The liver had the highest levels of $\mathrm{Zn}, \mathrm{Pb}$ and $\mathrm{Cd}$. The gill had the highest concentration of $\mathrm{Cu}$. Zinc accumulates in the gills of fish and this designates a depressing effect on tissue respiration leading to hypoxia which results in death [20]. The level of $\mathrm{Fe}$ in the bone was significantly different from that in the gill and muscle. There was a significant decrease in the $\mathrm{Zn}$ and $\mathrm{Ni}$ concentrations of the bone from that 
of the gill and liver. The level of $\mathrm{Pb}$ in the liver was significantly higher than the bone and gill. In Sardinella longiceps, Fe concentration (6.28 $\pm 0.08 \mathrm{mg} / \mathrm{kg}$ ) was highest in the gill. Cd was detected in liver and muscle. The concentrations of $\mathrm{Fe}, \mathrm{Zn} \mathrm{Cu}$ and $\mathrm{Ni}$ were highest in the gill. The liver had the highest levels of $\mathrm{Pb}$ and $\mathrm{Cd}$. In addition, Cd was not detected in the bone and gill. There was a significant decrease in the $\mathrm{Fe}$ concentrations in the bone from that in the other tissues. The level of $\mathrm{Cu}$ in the bone was also significantly different from that in the gill and liver. The level of $\mathrm{Ni}$ in the liver was significantly different from that in the bone and gill. There was significant decrease in $\mathrm{Pb}$ concentration in the liver from those in the bone and muscle (Table 1).

In Platax scalaris, Fe concentration was highest in all the tissues while $\mathrm{Cd}$ was not detected. The gill had the highest levels of $\mathrm{Fe}, \mathrm{Cu}, \mathrm{Ni}$ and $\mathrm{Pb}$.
The concentration of $\mathrm{Zn}$ was highest in the liver. There was significant increase in $\mathrm{Fe}$ concentration in the muscle from the gill and liver. The level of $\mathrm{Zn}$ in the bone was significantly reduced in the muscle. There was significant decrease in $\mathrm{Cu}$ and $\mathrm{Pb}$ concentrations of the gill from the bone and muscle. $\mathrm{Ni}$ concentration of the bone was significantly increased than that in the muscle, liver and gill (Table 1).

In Merluccius merluccius, Fe concentration was highest in bone, gill, liver and muscle while $\mathrm{Cd}$ was not detected. The highest concentrations of $\mathrm{Fe}, \mathrm{Zn}, \mathrm{Cu}, \mathrm{Ni}$ and $\mathrm{Pb}$ were found in the gill. The lowest concentrations of the metals studied were found in the bone. There was significant decrease in Ni concentration of the gill from the bone, muscle and liver. The level of $\mathrm{Pb}$ in the liver was significantly different from the bone and gill (Table 1).

Table 2: $\quad$ Standards of maximum permissible level of heavy metals in the fish samples and values from this study $(\mathrm{mg} / \mathrm{kg})$.

\begin{tabular}{lcccccc}
\hline References & Fe & $\mathbf{Z n}$ & $\mathbf{C u}$ & $\mathbf{N i}$ & $\mathbf{P b}$ & $\mathbf{C d}$ \\
\hline WHO (2006) [21] & 14.80 & 12.00 & 7.80 & 5.48 & 3.44 & - \\
EC (2005) [25] & - & - & - & - & 0.2 & 0.05 \\
FAO (2003) [23] & - & - & - & $0.5-0.6$ & 0.2 & 0.01 \\
EU (2001) $\boldsymbol{\mu g} / \mathbf{g}[\mathbf{2 2}]$ & - & - & 10 & - & 0.1 & - \\
FEPA (2003) [24] & - & 50 & 20 & $0.5-10$ & 0.2 & 0.2 \\
This study & 6.12 & 4.92 & 4.08 & 3.28 & 2.32 & 0.64 \\
\hline
\end{tabular}

The levels of $\mathrm{Fe}, \mathrm{Zn}$ and $\mathrm{Cu}$ determined in all the tissues of the fish samples studied were lower than the maximum in the guidelines listed in Table 2. All the tissues had elevated levels of $\mathrm{Ni}$ beyond the maximum permissible level $(0.5$ $0.6 \mathrm{mg} / \mathrm{kg}$ ) recommended by FAO [23]. All the tissues in the fish studied displayed levels of $\mathrm{Pb}$ $(0.72 \pm 0.08-2.32 \pm 0.00 \mathrm{mg} / \mathrm{kg})$ higher than the permissible level of $0.2 \mathrm{mg} / \mathrm{kg}$ [25]. Cd was detected in the liver and muscle of Sardinella longiceps while it was found only in the liver of Scomber scombrus. The highest concentration of $\mathrm{Cd}(0.6 \pm 0.4 \mathrm{mg} / \mathrm{kg})$ found in the muscle was higher than the value proposed in the literature (Table 2).

Table 3:

Table 3 :

\begin{tabular}{lccccccc}
\hline Sample & $\mathbf{F e}$ & $\mathbf{Z n}$ & $\mathbf{C u}$ & $\mathbf{N i}$ & \multicolumn{2}{c}{$\mathbf{P b}$} & $\mathbf{C d}$ \\
\hline Scomber scombrus & $5.48 \pm 0.24$ & $2.76 \pm 0.20$ & $1.72 \pm 4.00$ & $1.28 \pm 0.20$ & $0.36 \pm 0.08$ & $\mathrm{ND}$ \\
Sardinella longiceps & $5.88 \pm 6.00$ & $3.16 \pm 6.80$ & $2.64 \pm 0.48$ & $2.56 \pm 0.04$ & $1.28 \pm 0.04$ & $0.6 \pm 0.4$ \\
Platax scalaris & $4.00 \pm 4.00$ & $2.84 \pm 0.80$ & $2.24 \pm 0.16$ & $1.88 \pm 0.08$ & $1.36 \pm 0.04$ & ND & \\
Merluccius merluccius & $5.48 \pm 0.80$ & $4.32 \pm 0.28$ & $3.68 \pm 0.04$ & $2.32 \pm 0.08$ & $1.92 \pm 0.04$ & ND \\
\hline
\end{tabular}

The gills accumulated high concentrations of $\mathrm{Fe}$, $\mathrm{Zn}, \mathrm{Cu}, \mathrm{Ni}$ and $\mathrm{Pb}$. The concentrations of heavy metals in gills are a reflection of heavy metals in water because gills are directly in contact with the water and also have the thinnest epithelium when compared to other organs [26]. The muscle had low levels of some of these metals when compared with other organs. This may be because it is not an active tissue in accumulating heavy metals $[\mathbf{2 7}, \mathbf{2 8}]$.

The general trend for the metals in the fish samples was $\mathbf{F e}>\mathbf{Z n}>\mathbf{C u}>\mathbf{N i}>\mathbf{P b}>\mathbf{C d}$. The results obtained indicate the strong bioaccumulation of these heavy metals in the active tissues. 
Table 3 shows the concentrations of heavy metals in the muscle of the selected fish $(\mathrm{mg} / \mathrm{kg})$. The muscle is the edible part of the fish and the different fish species displayed varied levels of heavy metals in their muscles. This could be due to species dependence of metal bioaccumulation, feeding habits and habitats [29] in addition to size, and age [30]. The levels of $\mathrm{Pb}$ and $\mathrm{Cd}$ obtained were higher than the limit values proposed by European Community [25] and could be said to make the fish samples unfit for consumption, though large quantities of the fish species $(100-880 \mathrm{~g})$ have to be taken daily by a person (Table 4) for it to be harmful to human health [31]. Among all the fish studied, Sardinella longiceps has the highest concentrations of $\mathrm{Fe}, \mathrm{Ni}$ and $\mathrm{Cd}$ while highest concentrations of $\mathrm{Zn}, \mathrm{Cu}$ and $\mathrm{Pb}$ were found in Merluccius merluccius.

Table 4: Allowable consumption rates of heavy metals in the muscle of fish samples

\begin{tabular}{|c|c|c|c|c|c|c|c|}
\hline & Fish specie & $\mathbf{F e}$ & $\mathbf{Z n}$ & $\mathbf{C u}$ & $\mathbf{N i}$ & $\mathbf{P b}$ & Cd \\
\hline & Scomberscombrus & 7.75 & 6.59 & 1.41 & 0.95 & 0.08 & ND \\
\hline \multirow{4}{*}{$\begin{array}{l}\text { Daily } \\
{\left[\mathrm{CR}_{\lim }\right.} \\
(\mathrm{kg} / \mathrm{d})]\end{array}$} & Sardinellalongiceps & 7.23 & 5.76 & 0.92 & 0.47 & 0.02 & 0.10 \\
\hline & Plataxscalaris & 10.62 & 6.41 & 1.08 & 0.65 & 0.02 & ND \\
\hline & Merlucciusmerluccius & 7.75 & 4.22 & 0.66 & 0.52 & 0.02 & ND \\
\hline & Scomberscombrus & 54.27 & 46.18 & 9.88 & 6.64 & 0.59 & ND \\
\hline \multirow{4}{*}{$\begin{array}{l}\text { Weekly } \\
{\left[\mathrm{CR}_{\mathrm{wm}}\right.} \\
(\mathrm{kg} / \mathrm{w})]\end{array}$} & Sardinellalongiceps & 50.58 & 40.33 & 6.44 & 3.32 & 0.17 & 0.71 \\
\hline & Plataxscalaris & 74.38 & 44.88 & 7.59 & 4.52 & 0.16 & ND \\
\hline & Merlucciusmerluccius & 54.28 & 29.51 & 4.62 & 3.66 & 0.11 & ND \\
\hline & Scomberscombrus & 52978.36 & 45080.95 & 9645.23 & 6480.39 & 576.03 & ND \\
\hline \multirow{3}{*}{$\begin{array}{l}\text { Monthly } \\
{\left[\mathrm{CR}_{\mathrm{mm}}\right.} \\
\left.\left(\mathrm{mm}^{-1}\right)\right]\end{array}$} & Sardinellalongiceps & 49374.39 & 39374.51 & 6284.01 & 3240.19 & 162.01 & 691.24 \\
\hline & Plataxscalaris & 72580.36 & 43811.08 & 7406.16 & 4412.18 & 152.48 & ND \\
\hline & Merlucciusmerluccius & 52978.36 & 28801.73 & 4508.09 & 3575.39 & 108.01 & ND \\
\hline
\end{tabular}

The allowable consumption for one day would not essentially cause either chronic or acute health effects. However, consumption rate over a long period of time may be harmful to human health [34]. In Table 4, the highest allowable consumption rate for a day was found in $\mathrm{Fe}$ $(10.62 \mathrm{~kg} / \mathrm{d})$ in Platax scalaris. The allowable consumption rates in $\mathrm{Zn}, \mathrm{Cu}, \mathrm{Ni}$ and $\mathrm{Pb}$ were $6.59,1.41,0.95$ and $0.08 \mathrm{~kg} / \mathrm{d}$ respectively in Scomber scombrus. In Sardinella longiceps, the allowable consumption rate for $\mathrm{Cd}$ was 0.10 $\mathrm{kg} / \mathrm{d}$. Consumer may ingest heavy metals which has the ability to cause adverse health effects through the consumption of the fish samples.

The highest allowable consumption rate for a week was found in $\mathrm{Fe}(74.38 \mathrm{~kg} / \mathrm{w})$ in Platax scalaris. The highest allowable consumption rate for a week in $\mathrm{Zn}, \mathrm{Cu}, \mathrm{Ni}$ and $\mathrm{Pb}$ were 46.18 , $9.88, \quad 6.64$ and $0.59 \mathrm{~kg} / \mathrm{w}$ respectively in Scomber scombrus. In Sardinella longiceps, the allowable consumption rate for $\mathrm{Cd}$ was 0.71 $\mathrm{kg} / \mathrm{w}$ (Table 4).

The highest allowable monthly consumption rate was found in $\mathrm{Fe}\left(72580.36 \mathrm{~mm}^{-1}\right)$ in Platax scalaris. The highest allowable consumption 
rate for month in $\mathrm{Zn}, \mathrm{Cu}, \mathrm{Ni}$ and $\mathrm{Pb}$ were $45080.95,9645.23,6480.39$ and $576.03 \mathrm{~mm}^{-1}$ respectively in Scomber scombrus. The highest allowable consumption rate in $\mathrm{Cd}$ was $691.24 \mathrm{~mm}^{-1}$ in Sardinella longiceps (Table 4).

Table 5: $\quad$ Target Hazard Quotient (THQ) intake and Total Hazard Index (HI) of Fe, Zn, Cu, $\mathrm{Ni}, \mathrm{Pb}$ and $\mathrm{Cd}$ in the muscle of the fish samples

\begin{tabular}{|c|c|c|c|c|c|c|c|}
\hline \multirow[t]{2}{*}{ Fish Specie } & \multicolumn{6}{|c|}{$\begin{array}{c}\text { Total Hazard Quotient } \\
\text { (THQ) }\end{array}$} & \multirow{2}{*}{\begin{tabular}{l}
\multicolumn{1}{c}{ Total } \\
Hazard \\
Index \\
HI \\
\end{tabular}} \\
\hline & $\mathbf{F e}$ & Zn & $\mathrm{Cu}$ & $\mathbf{N i}$ & $\mathbf{P b}$ & Cd & \\
\hline Scomber scombrus & 0.135 & 0.158 & 0.739 & 1.100 & 12.375 & ND & 14.507 \\
\hline Sardinella longiceps & 0.144 & 0.181 & 1.134 & 2.200 & 44.000 & 10.312 & 57.973 \\
\hline Platax scalaris & 0.098 & 0.162 & 0.962 & 1.615 & 46.750 & ND & 49.589 \\
\hline Merluccius merluccius & 0.135 & 0.247 & 1.581 & 1.993 & 31.625 & ND & 35.582 \\
\hline
\end{tabular}

Table 5 depicts the Target Hazard Quotient intake and total hazard index of the heavy metals in the muscle of the various fish samples. Khan and co-workers [32] reported that THQ values greater than 1 indicate potential health risk from the metals and exposure through consumption of fish may likely lead to deleterious effects in human. The higher the THQ value, the higher the probability of hazard risk to the human body. The health risks related to THQ values of $\mathrm{Ni}$ and $\mathrm{Pb}$ were highest among all the heavy metals studied. THQ values for $\mathrm{Cu}$ in Sardinella longiceps and Merluccius merluccius were higher than 1. In Sardinella longiceps, THQ value for $\mathrm{Cd}$ was 10.312 indicating risk to health. The consumers of these fishes are at a risk due to elevated $\mathrm{Ni}$ and $\mathrm{Pb}$ THQ values with potential for adverse health effects. The highest THQ value was found in $\mathrm{Pb}$ (46.750) for Plataxscalaris. THQ values in $\mathrm{Fe}$ and $\mathrm{Zn}$ were all below 1 in all the fish samples and those metals do not pose health risk to consumers of the fish [33].

The total hazard index (HI) was derived from the summation of THQs of all the heavy metals studied. The highest values of HI were found in Sardinella Longiceps while the lowest values were obtained in Scomberscombrus. Hazard quotient based risk assessment method does not promote a quantitative estimate for the probability of an exposed population experiencing a reverse health effect but rather provides an indication of the risk level due to exposure to pollutants.

\section{Conclusion}

The levels of $\mathrm{Fe}, \mathrm{Zn}$ and $\mathrm{Cu}$ determined in all the tissues of the fish samples were lower than the maximum levels and guidelines $[\mathbf{2 3}, \mathbf{2 5}]$ except for $\mathrm{Ni}$ and $\mathrm{Pb}$. It was only in Scomberscombrus and Sardinellalongiceps that $\mathrm{Cd}$ was detected. The concentrations of all heavy metals in the fish samples were highest in the gills. Fe was the metal with the highest concentration in all the tissues. The muscle which is the edible part of the fish recorded low levels for some of these heavy metals compared to other tissues. The muscle of Sardinellalongiceps had elevated level of $\mathrm{Cd}$ compared to maximum levels and guidelines.

The THQ values for $\mathrm{Fe}$ and $\mathrm{Zn}$ in the muscles of the fish indicated no risk from the fish consumption while that for $\mathrm{Ni}$ and $\mathrm{Pb}$ indicated high risk from the fish consumption for most of the health risks related to the heavy metals in all the fish samples. There could also be health risks from $\mathrm{Cu}$ in Merlucciusmerluccius as well as $\mathrm{Cu}$ and $\mathrm{Cd}$ in Sardinellalongiceps. Consuming fish species with metals of high THQ on a large scale for a long period could be unsafe.

\section{References}

1. Eishler, R. (1988). Zinc Hazard to Fish, Wildlife and Invertebrates: A Synoptic Review US Fish, Wildlife Service. Biology of Reproduction 85: 1 - 12.

2. Kazium, U., Esengul, K., Metin, B., Muhammed, D., Yunus, E. Mustafa, K., Cigdem, O. and Ferda, O. (2008). The Comparison of Heavy Metal Accumulation Ratios of Some Fish 
Species in Enne Dame Lake, Kutahya, Turkey. Environmental Monitor Assessment 157: 355 - 362.

3. Gumgum, B., Unlu, E., Tez, Z. and Gulsun, Z. (1994). Heavy Metal Pollution in Water, Sediment and Fish from the Tigns River in Turkey. Chemosphere 290(1): 111 - 116.

4. Lee, Y. H. and Stuebing, R. B. (1990). Heavy Metal Contamination in the River Toad, Bufojuxtasper (Inger), near a Copper Mine in East Malaysia. Bulletin of Environment Contamination and Toxicology 45: 272 - 279.

5. Terra, B. F., Araujo, F. G., Calza, C. F., Lopes, R. T. and Teixeira, T. P. (2008). Heavy Metals in Tissues of Three Fish Species from Different Trophic Levels in a Tropical Brazilian River. Water Air Soil Pollution 187: 278 - 284.

6. Romeo, M., Siau, Y., Sidoumou, Z. and Gnassia-Barelli, M. (1999). Heavy Metal Distribution in Different Fish Species from the Mauritania Coast. Science Total Environment 232: 169 175.

7. Beijer, K. and Jernelov, A. (1986). Sources, Transport and Transformation of Metals in the Environment. Handbook on the Toxicology of Metals. Elsevier, Amsterdam pp 68-84.

8. Selda, O. T. and Nurşah, A. (2012). Relationship of Heavy Metals in Water, Sediment and Tissue with Total Length, Weight and Seasons of Cyprinuscarpio L., 1758 from Isikli Lake (Turkey). Pakistan Journal of Zoology 44(5): 1405 - 1416.

9. Aderinola, O. J., Clarke, E. O., Olarinmoye, O. M., Kusemiju, V. and Amatekhai, M. A. (2009). Heavy Metals in Surface Water, Sediments, Fish and Periwinkles of Lagos Lagoon. American- Eurasian Journal of Agricultural and Environmental Science 5(5): 609 - 617.

10. Guven, K., Ozbay, C., Unlu, E. and Satar, A. (1999). Acute Lethal Toxicity and Accumulation of Copper in Gammarus pulex (L.) (Amphipoda). Turkish Journal of Biology 23: 513 521.
11. Demirezen, D. and Aksoy, A. (2004). Accumulation of Heavy Metals in Typhaangustifolia (L.) and Potamogetonpectinatus (L.) Living in Sultan Marsh, Kaysen, Turkey. Chemosphere 56: 685 - 696.

12. Farkas, A., Salanki, J. and Specziar, A. (2002). Relation between Growth and the Heavy Metal Concentration in Organs of Bream Abramisbrama $L$. Populating Lake Balaton. Archives Environmental Contamination Toxicology 43: 236 - 243.

13. Al-Yousuf, M. and El-Shahawi, M. (1999). Trace Metals in Lethrinuslentjan Fish from the Arabian Gulf, Ras AlKhaimah, United Arab Emirates: Metal Accumulation in Kidney and Heart Tissues. Bulletin of Environmental Contamination Toxicology 62: 293 300.

14. European Food Safety Authority (EFSA) (2005). Opinion of the Scientific Panel on Contaminants in the Food Chain [CONTAM] related to the Safety Assessment of Wild and Farmed Fish.

Available at http://www.efsa.europa.eu/EFSA/efsa_1 ocale-1178620753812 11786 20762697.htm. Date retrieved: 11 July, 2006.

15. Nwabunike, N. O. (2016). Bioaccumulation of Heavy Metals on Fish Fin over Two Years. Journal of Fisheries and Livestock Production 4: 170 - 176.

16. Pandey, S., Parvez, S., Ansari, R. A., Ali, M., Kaur, M., Hayat, F., Ahmad, F. and Raisuddin, S. (2008). Effects of Exposure to Multiple Trace Metals on Biochemical, Histological and Ultrastructural Features of Gills of a Freshwater Fish, Chanapunctuate (Bloch). Chemico - Biological Interactions 174: 183 - 192.

17. Romeo, M., Siau, Y., Sidoumou, Z. and Gnassia-Barelli, M. (1999). Heavy Metal Distribution in Different Fish Species from the Mauritania Coast. Science Total Environment 232: 169 175. 
18. Wong, C., Wong, P. and Chu, L. (2001). Heavy Metal Concentrations in Marine Fishes Collected from Fish Culture Sites
in Hong Kong. Archives of Environmental Contamination Toxicology 40: 60 - 69.

19. United State Environmental Protection Agency (USEPA) (2000). Guidance for Assessing Chemical Contaminant Data for Use in Fish Advisory, II: Risk Assessment and Fish Consumption Limits. US Environmental Protection Agency. Washington (D.C.), EPA 823B-00-008.

20. Olaifa, F. E., Olaifa, A. K. and Onwude, T. E. (2004). Lethal and Sub-Lethal Effects of Copper to the African Catfish (Clariasgariepinus) Juveniles. African Journal of Biomedical Research 7: 65 70.

21. World Health Organization (WHO) (2006). Guidelines for Drinking Water Quality (Recommendations) WHO, Geneva, Switzerland, pp 130.

22. European Union (EU), (2001). Commission Regulation as Regards Heavy Metals, Directive 2001/22/EC, No 466.

23. Food and Agriculture Organization (FAO) (2003).Food and Agriculture Organization of Heavy Metals Regulations- Faolex Legal Notice nos 66/2003.

24. Federal Environmental Protection Agency (FEPA) (2003).Guidelines and Standards for Environmental Pollution Control in Nigeriapp 238.

25. European Community (EC) (2005). European Community Commission Regulation. Official Journal of the European Union 78: L16/43- L16/45.

26. Bebianno, M. J., Geret, F. P., Serafim, M. A., Coelho, M. R., Gnassia-Barelli, M. and Rameo, M. (2004). Biomakers in Ruditapesdecussatus: A Potential Bioindicator Species. Biomarker 9: 305 $-330$.

27. Karadede, H. and Unlu, E. (2000). Concentrations of some Heavy Metals in Water, Sediment and Fish Species from the Ataturk Dam Lake (Euphrates), Turkey. Chemosphere 41(9): 1371 1376.

28. Bahnasawy, M., Khidri, A. and Dheina, N. (2009). Seasonal Variations of Heavy Metals Concentrations in Mullet (Mugilcephalus) and Liza ramada (Mugilidae) from Lake Manzala, Egypt. Journal of Applied Science Research 5: $845-852$.

29. Yilmaz, A. (2005). Comparison of Heavy Metals Level of Grey Mullet (Mugilcephalus L) and Sea Bream (Sparusaurata L.) Caught in Uskenderun Bay, Turkey. Turkey Journal of Veterinary Animal Science 29: 257 - 262.

30. Canli, M. and Atli, G. (2003). The Relationship between Heavy Metals $(\mathrm{Cd}, \mathrm{Cr}, \mathrm{Cu}, \mathrm{Fe}, \mathrm{Pb}$ and $\mathrm{Zn})$ Levels and the Size of Six Mediterranean Fish Species. Environmental Pollution 121: 129 - 136.

31. Kamal, J. E., Shareef, K. M. and Nizam, M. E. (2013). Heavy Metal Concentrations in Some Commercially Important Fishes and their Contribution to Heavy Metals Exposure in Palestinian People of Gaza Strip, Palestine. Journal of the Association of Arab Universities for Basic and Applied Sciences 13: 44 51.

32. Khan, S., Cao, Q., Zheng, Y. M., Huang, Y. Z. and Zhu, Y. G. (2008). Health Risks of Heavy Metals in Contaminated Soils and Food Crops Irrigated with Waste Water in Beijing, China. Environmental Pollution 3: 686 692.

33. United State Environmental Protection Agency (USEPA) (2011). USEPA Regional Screening Level (RSL) Summary Table.

34. Jakus, P. and Krupnick, A. J. (2002).The Benefits and Costs of Fish Consumption Advisories for Mercury, Resources for the Future, Washington, DC.

Available at http://www.rff.org Date retrieved: $22^{\text {nd }}$ May, 2019. 